\title{
IAMJ
}

INTERNATIONAL

AYURVEDIC

MEDICAL JOURNAL

\section{CLINICAL ASSESSMENT OF THE ROLE OF KANSA HARITAKI AND VIRECHANA IN THE MANAGEMENT OF AMAVATA}

\author{
Rita Singh ${ }^{1}$, M. S. Baghel ${ }^{2}$, Anurag Singh Rajput ${ }^{3}$ \\ ${ }^{1}$ Associate Professor, Department of Roga Nidan Evum Vikriti Vigyan, Pt. Khushilal Sharma Government \\ Ayurveda College \& Institute, Bhopal, Madhya Pradesh, India \\ ${ }^{2}$ Former Director IPGT \& RA, Gujarat Ayurveda University Jamnagar (India), Ayurveda Chair Hon' Professor, \\ University of Debrecen, Hungary \\ ${ }^{3}$ Principal and Professor, Mansarovar Ayurvedic Medical College, Hospital \& Research Centre, Bhopal, Madhya \\ Pradesh, India; Director, Mrityunjay Ayurveda, Bhopal, Madhya Pradesh, India
}

Corresponding Author: vd.ritu@gmail.com

\section{https://doi.org/10.46607/iamj04p4062020}

(Published online: September 2020)

Open Access

(C) International Ayurvedic Medical Journal, India 2020

Article Received:08/09/2020 - Peer Reviewed:24/09/2020 - Accepted for Publication:30/09/2020

Check for updates

\section{ABSTRACT}

Amavata is a clinical condition described in Ayurveda that closely resembles with the clinical features of Rheumatoid Arthritis. A Clinical Study was conducted at IPGT and RA, Jamnagar in Kaya Chikitsa department to evaluate the efficacy of Virechan Karma with Eranda Taila and Trivrita Kwatha in patients suffering from Amavata and compared with the trial drug Kansa Haritaki described in Charak Samhita. Efficacy of both of these was compared with the known common drug Trayodashanga Guggulu. In this study, 38 patients of Amavata were registered, of which 29 patients completed the course of the treatment and 9 patients discontinued before completion of course against medical advice. The disease was diagnosed on the basis of signs and symptoms as described in Ayurvedic and Modern text, aided by American Rheumatism Association Criteria (1988). RA factor test was done in all the patients. The Routine Blood examination (CBC, ESR) with Serum Uric acid, Urine and Stool examination was done to rule out other pathological conditions. 
Keywords: Amavata, Rheumatoid Arthritis, Virechana Karma.

\section{INTRODUCTION}

Amavata is a distressing disease of Madhyama RogaMarga as it affects Sandhis \& Hridayamarma in which formed Ama is carried by the vitiated Vata to Trikapradesha and Sandhisthana making the whole body stiff $^{1}$. The disease is characterized by Sandhishoola, Sandhishotha, Jwara etc. It's a systemic disorder where digestive and metabolic mechanisms are involved i.e. Amavata is not simply a joint disorder but a systemic constitutional disorder involving whole of the body. Though Ama \& Vata are the prevailing pathogenic factors, the disease represents Tridoshic vitiation. The joints are major victims of such a disease because they are major seats of Kapha $\&$ as we know Ama has physical similarity to $\mathrm{Kapha}^{2}$.From the modern point of view, this disease looks similar to Rheumatoid Arthritis in its clinical appearance which is one of the commonest cause of physical impairment in the society. The lives of more than one million people are physically impaired by Rheumatoid Arthritis and one-fifth of these are severely disabled ${ }^{3}$.Amavata is not a fatal disease but due to its chronicity \& crippling deformity it is responsible for great loss of national manpower as no other disease and hence the source of earning making it a biggest worldwide burning problem irrespective of races. The ratio of female to male is approximately $3: 1^{4}$.

An enormous amount of research work has been done in the management of Amavata. Some effective drugs have also been selected but none of them can be considered as specific. All systems of medicines are looking with a hope towards Ayurveda to overcome this challenge.

For the present study on Amavata as Shamana therapy 1. Kansa Haritaki $i^{5}$ was chosen and as Shodhana therapy 2. Virechana ${ }^{6}$. Many works with Virechana Karma on 3. Amavata has been successfully carried out. To evaluate the effect of the results of Shamana therapy with 4. and without Shodhana, this study was conducted. 5. Both the above therapies chosen to fulfill the regimen of specific treatment of Amavata are mentioned in Chakradutta.

\section{Aim \& Objectives:}

1. To study the detailed etiopathogenesis and prevalence of Amavata.

2. To evaluate the efficacy of trial drug Kansa Haritaki in the management of Amavata.

3. To evaluate the efficacy of Virechana Karma with Erandataila \& Trivritachurna.

4. To compare the efficacy of above two with the known common drug TrayodoshangaGuggulu.

\section{Material \& Methods:}

Conceptual Study-Detailed study of Amavata was carried out in relation to Rheumatoid Arthritis and the drugs chosen for Shamana and Shodhana therapies in the OPD \& IPD of Kayachikitsa Department, IPGT \& RA, Jamnagar.

\section{Clinical Study-}

In the present study, 38 patients of Amavata consulting the OPD and IPD of Kayachikitsa Department of IPGT \& RA, Jamnagar were registered, of which 29 patients completed the course of the treatment and 9 patients discontinued before completion of course against medical advice. The disease was diagnosed on the basis of sign and symptoms as described in Ayurvedic and Modern test, aided by ARA criteria (1988). RA factor test was done in all the selected patients. On the basis of a special proforma prepared incorporating all signs and symptoms, detailed history was taken, and physical examination was done. Also, Routine Blood examination CBC, ESR and serum uric acid and also Urine and Stool examination were done to rule out other pathological conditions.

\section{Exclusion Criteria:}

Chronicity of more than 10 years.

Having severe crippling deformities.

Having Cardiac disease, Pulmonary tuberculosis, Diabetes Mellitus etc.

Manasabalapariksheenata.

Age less than 15 years and more than 60 years ${ }^{7}$.The selected patients were randomly divided into the following three groups: 
Shaman Group - 11 patients were treated in this group by Kansa Haritaki Avaleha in the dose of 10 grams two times a day with lukewarm water for $1 \frac{1 / 2}{2}$ months.

Shodhan Group - 9 patients were treated in this group with Virechan Karma followed by Kansa Haritaki. The patients of this group were given Virechana with Eranda Taila and Trivrita Kwath in the dose of $25-50 \mathrm{ml}$ and $50-75 \mathrm{ml}^{8}$ respectively followed by Kansa Haritaki internally as above. Abhyantara Snehapana with Shuddha Ghrita for 3-7 days. Sarwanga Snehana \& Bashpa Swedana for 3 days was done before Virechana drug was given.

Control Group - 9 patients were treated in this group with Trayodashanga Guggulu in the dose of $2 \mathrm{gms}$ thrice a day for $1 \frac{1}{2}$ months.

Follow up: Patients were reviewed after each 15 days for a period of $1 \frac{1 / 2}{2}$ months.

\section{Criteria for Assessment:}

In this study an effort has been made to follow the guideline laid down by the classical text of Ayurveda as well as American Rheumatism Association (1988). The Clinical improvement in the sign and symptoms of the disease in the patients have been assessed on the basis of Rogabala, Agnibala, Dehabala and Chetasabala ${ }^{10}$ which were scored as follows:

60 - Rogabala, 20 - Agnibala, 08 - Dehabala, 12Chetasabala

Rogabala has been given 60 score out of 100. It has been further divided into

$>30$ score to degree of disease activity which was assessed on the basis of modified American Rheumatism Association Criteria

$>30$ score assessed on the basis of symptoms of Amavata which was further subdivided as

$\checkmark 14$ score to Cessation of cardinal symptoms

$\checkmark \quad 10$ score to associated symptoms

$\checkmark \quad 6$ score to Physiological normalcy of Vata, Mutra and Pureesha.

Agnibala has been given 20 score out of 100 which has been further divided into

$>4$ score to Ruchirahar Kala

$>8$ score to Abhyavaharan Abhilasha

$>8$ score to Aharkala Samyakjaranam.
Dehabala has been given 8 score out of 100 which has been further divided into, 2 score to Swara Varna Yoga (Revitalization of speech and Lustre), 3 score to Sharir Upchaya (Increase in body mass /weight and gain in muscle wasting), 3 score to Bala Vriddhi (Increase in body strength), Chetasabala has been given 10 score out of 100 which was further divided as, 2 score to Nidralabha Yathakala(Sleep in proper time and cessation in symptoms), 2 score to Vaikarika Swapnanama Adarshanam (No pathological dreams), 3 score to (Mana Buddhi Indriya Avyapatti (Proper and unaltered functioning of mind, intellect and sensories), 3 score to Sukhencha Pratibodhnam.

\section{Overall Assessment of Therapy}

Overall assessment of all the therapies was done according to calculated score in terms of:

\begin{tabular}{|l|l|}
\hline Complete remission & 0 \\
\hline Marked improvement & $1-25$ \\
\hline Moderate improvement & $26-50$ \\
\hline Mild improvement & $51-75$ \\
\hline No improvement & $76-100$ \\
\hline
\end{tabular}

The results obtained were statistically analyzed and percentage of relief, Mean, SD, SE, t-value and pvalue were calculated by using the paired t-test and was presented along with explanatory notes, discussion and conclusion.

\section{Result}

The result of this study was assessed on the basis of changes observed after the treatment and was discussed parameter wise as here under Rogabala, $\mathrm{Ag}$ nibala, Dehabala and Chetasabala as follows:

The result in Group B that is Virechana Karma followed by Kansa Haritaki provided comparatively better result than other two groups. In Rogabala which includes SandhiShool (57.69\%), SandhiShotha (42\%), SandhiGraha (38.46\%) Sparshasahata (42\%) associated symptoms $(51.96 \%)$, physiological normalcy of Vata \& Mutra (50\%) and Pureesh (57.05\%), degree of disease activity (41.45\%). The result of effect on Agni Bala in Group B was also better than other two groups. It includes Abhyavaharan Abhilasha (45\%), Aharakala Samyak Jaranam (42.99\%) and Ruchi (52\%). Effect on Chetasa Bala of Group B was relief in Swara Varna Yoga (58.09\%) Shareer Upchaya (18.51\%) BalaVriddhi (30\%), Nidralabh Yatha Kala 
(40.57\%) and Sukhen Cha Pratibodhanam (54\%). In this group highest number of patients showed marked improvement (55.55\%). Most of these findings were also statistically highly significant.

In Group A, Kansa Haritaki was administered to patients showed average relief in sign and symptom. The relief of Roga Bala was Sandhi Shool (46.34\%), Sandhi Shoth (36\%), Sandhi Graha (36.61\%) Sparsh Asahata (33.33\%), associated symptoms (48.8\%), Physiological normalcy of Vata (33\%), Pureesh (50\%) and Mutra (50\%), Degree of disease activity (36.64\%). Effect on Agni Bala which includes Abhyavaharan Shakti (33.33\%), Aharakala Samyak Jaranam (33\%) and Ruchi (44.63\%). Effect of Chetasabala was Swara Varna Yoga (57\%), Sharir Upchaya (11.11\%), Bala Vriddhi (25.92\%), Nidralabh Yathakala (36.29\%) and Sukhencha Pratibodhanam (50\%). Statistically significance of these results was less in comparison to Group B. Result of Trayodashanga Guggulu (Group C) was in the third place with relief as Sandhi Shool (46.8\%), Shotha (33.03\%), Sandhi Graha (28.19\%), SparshAsaheta (25.68\%), associated symptoms(37.45\%), Physiological normalcy of Vata (42.85\%) Mutra and Pureesh (25\%), Degree of disease activity (29.73\%), Ruchi (33.24\%), Abhyavaharan Abhilasha (33.03\%), Ahaarkala Samyakjaranam (33.33\%), Sharira Upchaya (9.30\%), Bala Vriddhi $(22.22 \%)$, Nidralabha Yatha Kala (33.06\%) and Sukhencha Pratibodhanam (40.74\%)., So far is the total effect of treatment was concerned in all the three groups that is Group A- Kansa Haritaki, Group B Kansa Haritaki and Virechana, Group C - Trayodashanga Guggulu, none of the patients got complete remission, which shows the severity of the disease.

In Shodhana group (Group B) 55.55\% patients got marked improvement. In Shamana group (Group A) $33.36 \%$ patients and in Control group (Group C) $22.22 \%$ patients got marked improvement. $22.22 \%$ patients each of Shamana and Control group got moderate improvement and $18.18 \%$ patients of Shodhanagroup got moderate improvement. Minor improvement was found in $27.27 \%$ of patients in Group A, $11.11 \%$ patients in Group B and $22.22 \%$ patients in
Group C. No improvement was found in $18.18 \%$ of patients in Group A, $11.11 \%$ of patients in group B and $33.33 \%$ of patients in Group C. None of the patients in any group got complete remission.

In a nutshell, Kansa Haritaki with Virechana provided significantly better improvement in Roga Bala, Agni Bala, Deha Bala and Chetasa Bala than the other two groups. Kansa Haritaki administered after Shodhana (Virechana) with Eranda Taila and TrivritaKwatha provided better relief. So, it can be recommended for the management of Amavata.

\section{DISCUSSION}

Age- All the 38 patients registered for the present study were ranging from 15 to 60 years, of which maximum patients $(34.1 \%)$ were between 31 to 40 years age group, which was followed by $24.94 \%$ patients in the age group of 15 to 30 years. Observation of this study were in accordance with the finding of Rheumatoid Arthritis.

Sex- In this study majority of the patients were female (76.31\%) as compared to male patients (23.86\%). Textual references also reflect the predominance of Rheumatoid Arthritis in female.

Religion- Majority of the patients in this study was Hindu (86.84\%) which may be due to predominance of Hindu community in this particular region.

Occupation - Most of the women registered were housewives (76.31\%) which reflects the general occupation of majority of the female in this area.

Economic Status-Majority of the patients (50\%) were of middle economic status, while rest of the patients $(44.73 \%)$ were of poor and rich $(5.6 \%)$ economic status. It may be due to the fact that, this study was conducted in a Government Hospital where free treatment facilities are available. Another possibility was that middle- and lower-class people are more prone to stress and strain which may precipitate the disease Amavata.

Marital Status-In this study, majority of the patients $(93.10 \%)$ were married as they were from the middle age group.

Family History- $86.84 \%$ of the patients of this study reported negative family history of joint disorders 
where $13.15 \%$ reported positive family history. But to • give any conclusion regarding the relation of family history with the incidence of the disease Amavata, a large-scale survey of the patients is required.

Deha Prakriti-In this study it was found that maximum percent of patients $(55.26 \%)$ were possessing Kapha-VataPrakriti. In general, KaphaPrakriti will have Mandagni leading to Ama formation, which when provoked by Vata will get settled in respective Shleshma Sthana. So, it is justifiable that KaphaVataPrakriti persons are easily prone to Amavata.

Koshtha-In the present study, majority of the patients $60.52 \%$ had Krura Koshtha, which was followed by Madhyam Koshtha in $39.47 \%$ of the patients. In general, Vata and Kapha Prakriti persons have Krura and Madhyam Koshtha. It justifies the finding of Prakriti, asPrakriti distribution of this study reveals that maximum number of patients possess Kapha-VataPrakriti.

Rheumatoid Factor- $60.51 \%$ patients in this study were sero-positive. This observation corroborates very well with textual reference given in Davidson ${ }^{11}$

Nidan-Majority of the patients in the present study gave the history of Guru, Snigdha, Sheeta AharaSevan, Diwaswapa, Nishchalta, Shoka and Chinta. All these factors lead to Mandagani and consequently to the formation of $\mathrm{Ama}^{12}$. So, it can be concluded that all the above-mentioned factors play an important role in precipitation and aggravation of the disease Amavata.

\section{Probable mode of action of Virechan Karma}

In the present study, Virechana was administered with Eranda Taila and Trivrita Kwatha. Erand Taila is Vata Kapha Shamak having specific Vyadhihar that is Amavatahar action. Ricin present in it gets converted to Ricinoelic acid by lipase, which irritates bowel leading to Virechana. As it is having UshnaVeerya, it also does Pachan Karma (Amapachan). Trivrita is having glycoside, turpethine which cause purgation and is also Vata Kapha Shamak, which acts as Antidosha for the disease Amavata ${ }^{13}$. Action of Virechan on Amavata can be understood by the following properties of it ${ }^{14}$.
Virechana has direct effect on Agnisthana and hampered Agni is one of the initiated factors in Amavata. It pacifies the vitiated Kapha and Vatadosha.

- It has the property of StrotoVishodhana hence the Strotorodha in Amavata mainly in SandhiSthan is cleared by Virechana leading to relief of the symptoms.

Virechana is indicated in Sannipatika condition of morbidity and hence helpful in Amavata.

Virechana works well by clearing the morbid Doshas which adhere to Bahya that is Rasa etc. and Madhyama that is Marma, Asthi, SandhiRogaMarga with the Triyakagaman.

Virechana helps to normalize the Pratilomgati of Vata, which produces symptoms like Anaha, Antrakujan, Kukshikathinya, Kukshishool etc. in Amavata.

Acharya Charaka has given brief description of how Virechan Dravyas act in the body. The drugs Eranda Tail and TrivritaKwatha having Ushna, Teekshna, Sukshma properties reach to the heart by the virtue of their potency and circulate through the large and small Srotas and pervade the entire body.

Then they liquefy the morbid elements by virtue of its Aagney Guna and disjoins them by its Teekshna Guna. Then this liquefied morbid mass floating like honey in unctid vessels through the virtue of Anupranav Bhava of the drug and ultimately reaches Amashaya. From here it forces the morbid factors through the anal canal route due to the Bhautika predominance of the Jala and Prithvi and Adhobhaghar Prabhav leading to Virechana.

\section{Probable mode of action of Kansa Haritaki}

In the first stage of disease, Amotpatti is there and Kansa Haritaki does Amapachan as all the pharmo dynamic properties of Kansa Haritaki that is Laghu, Teekshna, Ruksha Guna, Katu-Tikta Rasa, UshnaVeerya are against the Guru Snigdha, Pichchil, Sheeta properties of Ama. Also, some effect of antioxidant property of Kansa Haritaki over Ama ${ }^{15}$ that is free radical must be there. Later the Yugapat Prakop of disease is checked by Vata Kaphahar action of the drug. Further Ama formation is stopped by the Deepaniya action, in the Srotoabhishyanda. It does Sroto Shodhana and relives the symptoms of Sandhi Shool, 
Shotha, Aalasya, Aruchi etc. by its synergetic Vedana Prashanam and Shothahar action. Also, the associated symptoms like Vibandha, Anaha etc. are reduced by 6 . Anulomana that is purgative property of the drug. As most of the drugs are Vata Kapha Shamaka and Agnivardhak so it is very suitable for the Samprapti Vighatan of the disease and to combat the main culprit, Vata and Kapha and Mandagini which are the root cause of Amavata.

\section{CONCLUSION}

As the disease Amavata, is a chronic disease of Madh- 9 . yam Rogamarga that is Marma-Asthi-Sandhi, less results were obtained and contributed for slow recovery. Patients of this disease require long duration of the therapy. However, result of this therapy provide good hope for the patients of Amavata. Kansa Haritaki being good Shothahara (anti-inflammatory), Vedana Prashmana (Analgesic) may prove a good drug for the management of the disease Amavata.

Kansa Haritaki administered after Virechana Karma with Trivrita Kwatha and Eranda Taila provided best relief. As Virechana corrects the digestive activity of Pitta, pacifies the vitiated Kapha and Vata, normalizes the PratilomGati of Vata and helps the drug to be better acted upon and absorbed in the body. Hence helps in the management of the disease Amavata.

\section{REFERENCES}

1. Charaka Samhita of Agnivesha Revised by Charaka and Dridabala with Hindi commentary, Shastri R. D. editor, edition 1984, Chaukhambha Sanskrit Series Varanasi p.237, Charak Chikitsa 11/48.

2. Madhava Nidana of Madhavakara with "Madhukosha" Vijay Rakshita and Shreekantha Datta commentary Vaidhya V. editor, Nirnaya Sagar Press Bombay; p.509, Ch.25/5.

3. Harrisons Principles of Internal Medicine, Edited by Fauci et al, Published by McGraw Hill medical publication $14^{\text {th }}$ International edition, Vol 2 p.1880, Ch. 314

4. Harrisons Principles of Internal Medicine, Edited by Fauci et al, Published by McGraw Hill medical publication $14^{\text {th }}$ International edition, Vol 2 p.1880, Ch.314.

5. Charak Samhita of Agnivesha Revised by Charaka and Dridabala with Hindi commentary, Shastri R. D. editor, edition 1984, Chaukhambha Sanskrit Series Varanasi, p. 366, Charak Chikitsa 12/50-52.

Chakradatta of Chakrapani with Vaidyaprabha Hindi vyakhaya, Tripathi I. D., Dwivedi R. N. editor, edition 3 1997: Chaukambha Sanskrit Sansthana Varanasi p.166 Chapter 25/1.

7. Harrisons Principles of Internal Medicine, Edited by Fauci et al, Published by McGraw Hill medical publication $14^{\text {th }}$ International edition, Vol 2 p.1880 Ch. 314.

8. Ayurvedic Panchkarma Vigyan, Kasture Shridhar Haridas editor, edition $3^{\text {rd }} 1994$, Baidyanath Ayurveda Bhawan p.336.

Bhava Prakasha of Bhava Mishra, Shastri B.S. editor, edition 2000 Chaukhambha Vidya Bhavana Varanasi Vol 2 p.240 Ch.24/117-121.

10. Charaka Samhita of Agnivesha Revised by Charaka and Dridabala with Hindi commentary, Shastri R. D. editor, edition 1984Chaukhambha Sanskrit Series Varanasi, p. 769-770, Charak Vimana 8/89.

11. Davidson's Principles and Practice of Medicines, Nicki R. Colledge, Brian R. Walkar and Stuart H. Ralston editor, p.1088-1092.

12. Charaka Samhita of Agnivesha Revised by Charaka and Dridabala with Hindi commentary, Shastri R. D. editor, edition 1984, Chaukhambha Sanskrit Series Varanasi, p. 460, Charak Chikitsa 15/42-43.

13. Dravyaguna Vigyana: Sharma P.V. editor. edition 2002 Chaukhambha Surbharati Academy Varanasi, Vol 2 p. 420421.

14. Ayurvedic Panchkarma Vigyan, Kasture Shridhar Haridas editor edition $3^{\text {rd }}$ 1994, Baidyanath Ayurveda Bhawan, p.374-383.

15. Charaka Samhita of Agnivesha Revised by Charaka and Dridabala with Hindi commentary, Shastri R. D. editor, edition 1984Chaukhambha Sanskrit Series Varanasi, p.336, Charak Chikitsa 12/52.

\section{Source of Support: Nil Conflict of Interest: None Declared}

How to cite this URL: Rita Singh et al: Clinical Assessment of the Role of Kansa Haritaki And Virechana in the Management of Amavata. International Ayurvedic Medical Journal \{online\} 2020 \{cited September, 2020\} Available from:

http://www.iamj.in/posts/images/upload/2474_2479.pdf 